\title{
Combined Medetomidine and Ketamine for Short-term Anaesthesia in Ferrets - a Clinical Study
}

\section{P. RAUŠER ${ }^{1}$, J. ZATLOUKAL ${ }^{2}$, A. NEČAS ${ }^{1}$, J. LORENZOVÁ $^{1}$, L. LEXMAULOVÁ $^{1}$}

${ }^{1}$ Department of Surgery and Orthopaedics, Small Animal Clinic,

University of Veterinary and Pharmaceutical Sciences, Brno, Czech Republic ${ }^{2}$ Department of Diagnostic Imaging, Small Animal Clinic,

University of Veterinary and Pharmaceutical Sciences, Brno, Czech Republic

\author{
Received September 25, 2001
}

Accepted June 19, 2002

\section{Abstract}

Raušer P., J. Zatloukal, A. Nečas, J. Lorenzová, L. Lexmaulová: Combined Medetomidine and Ketamine for Short-term Anaesthesia in Ferrets - a Clinical Study. Acta Vet. Brno 2002, 71: 243-248.

In a clinical study we evaluated the quality of anaesthesia by a combination of medetomidine and ketamine given at two different doses to perform standard surgical procedures in the ferret (e.g. anal sac removal, castration or ovariohysterectomy). Ferrets were intramuscularly administered medetomidine $(60 \mu \mathrm{g} / \mathrm{kg})$ in a combination with ketamine given at two different doses $(5 \mathrm{mg} / \mathrm{kg}$ in group A and $8 \mathrm{mg} / \mathrm{kg}$ in group B). Within several minutes all animals took up lateral recumbency, lost bottle the palpebral reflex and deep sensation except for three individuals receiving the lower ketamine dose, in which there was no deep sensation loss observed. Lower ketamin dose resulted in later loss of all evaluated parameters. It also reduced the time of their recovery (especially deep sensation). The loss of deep sensation after the higher ketamine dose was nearly twice as long as after the lower dose. Heart rate values were comparable in both groups and showed a decreasing tendency as well as the respiratory rate, which, however, differed in both groups from the $30^{\text {th }} \mathrm{min}$ of anaesthesia. The combination of medetomidine and ketamine is very effective for the anaesthesia in ferrets regarding the duration, myorelaxation and analgesia. Prolongation of this anaesthesia is possible with half ketamine doses.

$\alpha$-adrenergic drugs; dissociative anesthetics

The ferret (Mustela putorius furo) is becoming a more popular pet. The number of ferrets treated in our clinic increased nearly fifteenfold compared with the year 1994. Veterinary care of the ferret includes numerous examinations (biological sample collection, radiography or ultrasonography) (Hau ptman et al. 2001) or procedures (nail trimming, ear cleaning, oral prophylaxis, sterilization, anal sac removal, laparotomy, orthopaedic treatment). The use of sedation or anaesthesia is necessary for most of these procedures.

Anal sac removal is one of the most frequent procedures performed in the ferret. Between 1994 and 1999 it was performed in 56 individuals, amounting to $73 \%$ of all procedures requiring anaesthesia. Standard surgical procedures require anaesthesia providing good quality analgesia and muscle relaxation in the total duration of 30 to $60 \mathrm{~min}$ (Creed and Kainer 1981).

Several anaesthetic protocols for these procedures are available. Intramuscular anaesthesia is a commonly used technique. A number of injectable anaesthetics have been found suitable for the use in ferret. Dissociative anaesthetics, ketamine in particular, are highly favoured and used alone or in a combination with other substances for sedation or premedication such as $\alpha-2$ agonists (xylazine, medetomidine) (Ko et al. 1997), benzodiazepines (diazepam) (Moreland and Glaser 1985) or neuroleptics (acepromazine). Combinations of zolazepam-tiletamin (Payton and Pick 1989) or alphaxolone-alphadolone (Green et al.

Address for correspondence:

MVDr. Petr Raušer, Faculty of Veterinary Medicine University of Veterinary and Pherming Small Animal Clinic - Department of Surgery and Orthopaedics Palackého 1-3, 61242 Brno, Czech Republic
Phone: +420541562362

Fax: +420541562344

http://www.vfu.cz/acta-vet/actavet.htm 
1978) can also be used. Requirements for a quality anaesthesia are good analgesia, muscle relaxation and anaesthesia. These requirements are fulfilled mainly by the combinations of $\alpha-2$ agonists (providing good muscle relaxation, sedation and analgesia) and the dissociative anaesthetics ketamine enhancing the analgesia (the somatic one in particular).

Medetomidine is the latest $\alpha-2$ agonist used for sedation, analgesia and muscle relaxation in dogs and cats (Thurmon et al. 1996). It gradually replaces xylazine. The effects of medetomidine on cardiovascular and respiratory apparatus are described in rodents (Ko et al. 1992), dogs (Thurmon et al. 1994; Ko et al. 1994; Ko et al. 1996) and cats (Verstegen et al. 1991). Ko et al. (1997) mention the sedative and cardiorespiratory effects of medetomidine used alone or in a combination with butorphanol and ketamine in ferrets. Moreland and Glaser (1985) described the combination of xylazine and ketamine in the ferret (ketamine $25 \mathrm{mg} / \mathrm{kg}+$ xylazine $2 \mathrm{mg} / \mathrm{kg}$ ) inducing sufficient analgesia and muscle relaxation and, at the same time, cardiac arrhythmia.

The aim of this study was to evaluate clinically the anaesthetic effects of medetomidineketamine combination (a standard dose of medetomidine and two different doses of ketamine) on parameters limiting the course of anaesthesia during short surgical procedures. The main attention was paid to the level of deep sensation and the duration of its loss along with heart and respiratory rates.

\section{Materials and Methods}

Study groups of animals

In all, 37 clinically healthy ferrets (Mustela putorius furo) aged 5 to 36 months (13.1 \pm 9.79 months) and weighing 0.5 to $1.9 \mathrm{~kg}(1.16 \pm 0.38 \mathrm{~kg})$ was included in our study. There were 20 males and $17 \mathrm{females}$. Anaesthesia was performed as a part of routine clinical practice for short procedures such as anal sac removal (32 cases), castration of males ( 2 cases) and ovariohysterectomy ( 3 cases). The animals were fasted for $12 \mathrm{~h}$ prior to the anaesthesia and had free access to drinking water. Animals went through standard clinical preoperative examination.

Protocol of the experiment

The total number of 37 ferrets was divided into two groups. Group A and B included 10 males and 6 females (aged $8.8 \pm 3.5$ months and weighing $1.3 \pm 0.38 \mathrm{~kg}$ ) and 10 males and 11 females (aged $16.3 \pm 11.95$ months and weighing $1.0 \pm 0.35 \mathrm{~kg}$ ), respectively. Animals were anaesthetised by the combination of medetomidine in the dose of $60 \mu \mathrm{g} / \mathrm{kg}$ and ketamine in the dose of $5 \mathrm{mg} / \mathrm{kg}$ (group A) and $8 \mathrm{mg} / \mathrm{kg}$ (group B). Both substances were administered mixed in one syringe intramuscularly into semimembranosus and semitendinosus muscles. After the administration we measured the time necessary for the animal to assume lateral recumbency, palpebral reflex and deep sensation loss. Lateral recumbency time was recorded when the animal was unable to rise to sternal position on its own. Palpebral reflex was tested by touching the lower lid and considered to be present when the animal reacted by closing the lids or, otherwise, absent. Deep sensation was examined by a needle probing the interdigital skin of the thoracic extremity. It was evaluated as present when the animal reacted by moving the leg. After the animal took up lateral recumbency it was supplied with 3 EKG needle leaders in the area of the left and right axilla and the left pre-stifle skin fold in order to monitor and record heart rate using the DATEX Cardiocap II apparatus. Respiration was monitored by adspection of respiratory movements of the thorax. Heart and respiratory rates were determined $10 \mathrm{~min}$ after the administration of anaesthetics and at 10-min intervals for one hour. Restoration of deep sensation and individual reflexes were evaluated in the period of recovery using the same tests as during the induction of anaesthesia.

Statistical evaluation

We compared both groups of animals regarding the interval from the administration of anaesthetics to assume lateral recumbency, loss of palpebral reflexes and deep sensation as well as the duration of lateral recumbency and palpebral reflex loss. We also compared heart and respiratory rates in both groups. Because the requirement of agreement with the normal distribution was not fulfilled, we used non-parametric methods. Since we compared no-paired data, we used the non-parametric Mann-Whitney test.

\section{Results}

There were no statistically significant differences between both groups of animals in basic parameters such as the sex, age and weight. 
Lateral recumbency (Table 1)

Both doses of ketamine used with medetomidine resulted in lateral recumbency within several min - i.e. $2.2 \pm 0.6$ and $1.8 \pm 1.0 \mathrm{~min}$ in the group A nad B, respectively. Animals obtaining the lower ketamine dose $(5 \mathrm{mg} / \mathrm{kg})$ took up lateral recumbency later $(p<0.05)$ than animals administered the higher dose $(8 \mathrm{mg} / \mathrm{kg})$. Animals in the group A and $\mathrm{B}$ remained in lateral recumbency for $78.1 \pm 32.3$ and $100.0 \pm 35.4 \mathrm{~min}$, respectively. The difference between the group A and B in the duration of lateral recumbency was not statistically significant.

Table 1

Induction period and duration of sedative, analgetic and anaesthetic effects of a combination of medetomidine $(60 \mu \mathrm{g} / \mathrm{kg})$ and ketamine in two different doses $(5 \mathrm{mg} / \mathrm{kg}$ and $8 \mathrm{mg} / \mathrm{kg})$

\begin{tabular}{|c|c|c|}
\hline \multirow{2}{*}{} & \multicolumn{2}{|c|}{ Time (min) } \\
\cline { 2 - 3 } & $\begin{array}{c}\text { Group A } \\
\text { Medetomidine } \\
60 \mu \mathrm{g} / \mathrm{kg}+\text { ketamine } 5 \mathrm{mg} / \mathrm{kg}\end{array}$ & $\begin{array}{c}\text { Group B } \\
\text { medetomidine } \\
60 \mu \mathrm{g} / \mathrm{kg}+\text { ketamine } 8 \mathrm{mg} / \mathrm{kg}\end{array}$ \\
\hline $\begin{array}{c}\text { Induction } \rightarrow \text { assuming } \\
\text { lateral recumbency }\end{array}$ & $2.2 \pm 0.6$ & $1.8 \pm 1.0$ \\
\hline $\begin{array}{c}\text { Induction } \rightarrow \text { loss of } \\
\text { palpebral reflex }\end{array}$ & $5.0 \pm 1.8$ & $3.1 \pm 1.5$ \\
\hline $\begin{array}{c}\text { Induction } \rightarrow \text { loss of deep } \\
\text { sensation }\end{array}$ & $6.6 \pm 1.5^{*}$ & $4.0 \pm 2.0$ \\
\hline Lateral recumbency period & $78.1 \pm 32.3$ & $100.0 \pm 35.4$ \\
\hline Palpebral reflex loss period & $30.4 \pm 9.3$ & $36.1 \pm 10.5$ \\
\hline Deep sensation loss period & $15.7 \pm 11.9 *$ & $34.5 \pm 9.5$ \\
\hline
\end{tabular}

* there was no deep sensation loss in three animals

Palpebral reflex (Table 1)

Animals receiving the lower ketamine dose $(5 \mathrm{mg} / \mathrm{kg})$ lost palpebral reflex after $5.0 \pm 1.8$ min, which was later $(p<0.01)$ than in animals ones with the higher ketamine dose $(8 \mathrm{mg} / \mathrm{kg})$ loosing the reflex after $3.1 \pm 1.5 \mathrm{~min}$. There was no statistically significant difference in the duration of palpebral reflex loss between the group A and B.

Deep sensation (Table 1)

Animals receiving the lower ketamine dose $(5 \mathrm{mg} / \mathrm{kg})$ lost deep sensation within $6.6 \pm 1.5 \mathrm{~min}(p<0.01)$ as compared to the higher ketamine dose group loosing deep sensation within $4.0 \pm 2.0 \mathrm{~min}$. In three cases out of 16 animals receiving the lower dose there was no deep sensation loss noted. In this group of animals, deep sensation loss lasted for a shorter period $(p<0.01)$ than in animals receiving the higher dose of 8 $\mathrm{mg} / \mathrm{kg}(15.7 \pm 11.9$ and $34.5 \pm 9.5 \mathrm{~min}$, respectively).

Respiratory rate (Fig. 1)

The respiratory rate had a decreasing tendency in both groups of animals.

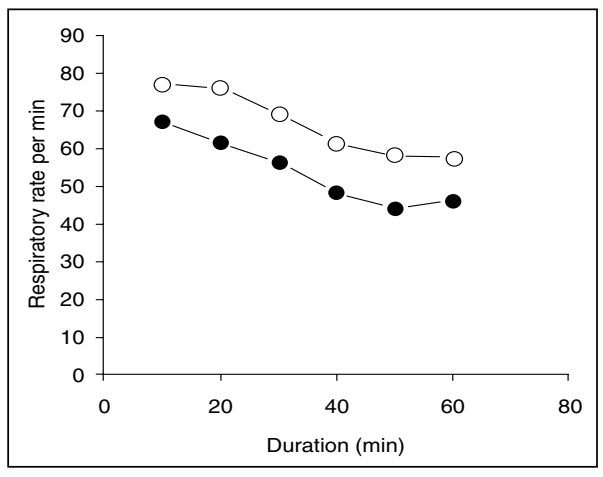

Fig. 1. Comparison of respiratory rates during anaesthesia by a combination of medetomidine $(60 \mu \mathrm{g} / \mathrm{kg})$ and ketamine in two different doses $(5 \mathrm{mg} / \mathrm{kg}$ and $8 \mathrm{mg} / \mathrm{kg}$ ) 


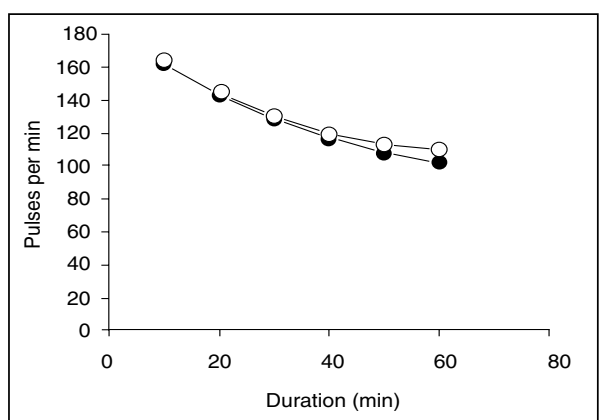

Fig. 2. Comparison of heart rates during anaesthesia by a combination of medetomidine $(60 \mu \mathrm{g} / \mathrm{kg})$ and ketamine in two different doses $(5 \mathrm{mg} / \mathrm{kg}$ and $8 \mathrm{mg} / \mathrm{kg}$ )
Differences between the group A and B were, except for the values obtained in the $30^{\text {th }} \mathrm{min}$, statistically significant $(p<0.05)$. The difference between both groups was even statistically highly significant $(p<0.01)$ during the $40^{\text {th }}$ and $50^{\text {th }}$ min.

\section{Heart rate (Fig. 2)}

The heart rate showed a decreasing tendency in both groups of animals. There were no statistically significant differences in the heart rate values between the group $A$ and $B$ found using the Mann-Whitney test.

\section{Discussion}

Following intramuscular injection in the dog and cat, medetomidine is quickly absorbed and its half time of distribution is less than $10 \mathrm{~min}$ (Salonen 1989). Studies on dogs (Thurmon et al. 1994) and rabbits (Ko et al. 1992) mention animals assuming lateral recumbency following administration of medetomidine alone within 5 min.

Ko et al. (1997) describe ferrets assuming lateral recumbency following administration of medetomidine alone or in a combination with other anaesthetic agents within $4 \mathrm{~min}$. Using the same substances as we did in our study, i.e. medetomidine and ketamine, but in different doses $(80 \mu \mathrm{g} / \mathrm{kg}$ of medetomidine $+5 \mathrm{mg} / \mathrm{kg}$ of ketamin), the above-mentioned authors found the ferrets assuming lateral recumbency within $2.2 \pm 0.4 \mathrm{~min}$. We got almost the same results $(2.2 \pm 0.6 \mathrm{~min})$ in our group A receiving $60 \mu \mathrm{g} / \mathrm{kg}$ of medetomidine $+5 \mathrm{mg} / \mathrm{kg}$ of ketamine. The period from induction to lateral recumbency was shorter $(1.8 \pm 1.0 \mathrm{~min})$ in the group B receiving $60 \mu \mathrm{g} / \mathrm{kg}$ of medetomidine $+8 \mathrm{mg} / \mathrm{kg}$ of ketamine. The higher ketamine dose can be considered the main cause of shortening of this period. The marked variation of the values was due to higher heterogeneity of age and body mass in our group of animals. Contrary to the results of Moreland and Glaser (1985), who used instead of medetomidine less potent xylazine $(2 \mathrm{mg} / \mathrm{kg})$ together with much higher dose of ketamine $(25 \mathrm{mg} / \mathrm{kg}$ ), we see that the time required to assume lateral recumbency following the use of medetomidine is much shorter. In view of this fact, administration of more potent $\alpha-2$ agonist medetomidine is essential for assuming lateral recumbency. Apart from sedative and muscle relaxing effects of medetomidine, there are also analgetic effects (Thourmon et al. 1996), which, however, are of much shorter duration compared to the sedative ones (Ko et al. 1997). This fact also proved to be true in our study for the combination of medetomidine and ketamine. After the lower ketamine dose analgesia lasts approximately one fifth of sedation, while the higher ketamine dose induces thrice shorter analgesia compared to the duration of sedation. Using the lower ketamine dose, there was even no analgesia achieved in three cases. In addition, we noted considerable individual differences in the duration of anaesthesia (deep sensation loss lasted 15.7 \pm 11.9 min in group A ferrets). According to Ko et al. (1997) the potentiation of analgesia is three to fourfold following the use of the medetomidine and ketamine as compared to the use of medetomidine alone. Comparing the use of less potent $\alpha-2$ agonist xylazine in combination with considerably higher dose of ketamine $(25 \mathrm{mg} / \mathrm{kg}$ ) (Moreland and Glaser 1985), the analgesia was half as long as in our study. This finding is similar to the results of Ko et al. (1997). The use of a less potent $\alpha-2$ agonist xylazine together with considerably higher dose of ketamine is in this case comparable to the use of only slightly higher medetomidine dose and lower 
ketamine dose. The reason may be the potentiation of analgetic effect of medetomidine and ketamine, when only moderate increases in the medetomidine dose cause effects comparable to the use of much higher ketamine doses (up to five times higher) together with xylazine.

The respiratory rate had a decreasing tendency in both groups of animals. Respiratory rate values in our study animals were considerably higher (up to twice) in comparison with those ones published by Ko et al. (1997). Comparable values were obtained only during the $50^{\text {th }}$ and $60^{\text {th }} \mathrm{min}$. Comparing both our groups we see statistically significant differences in the respiratory rate in the $30^{\mathrm{th}}, 40^{\text {th }}$ and $50^{\text {th }}$ min, which probably resulted from variances in age and body weight. Higher respiratory rate was found in older animals with a lower body weight. Higher body weight by approximately $0.3 \mathrm{~kg}$ in the case of such a small patient as the ferret seems to be a more important parameter for the evaluation of respiratory rates than the age, which differed by 7 months. Ko et al. (1997), working with animals of higher weight categories (1.5-2.2 kg), also mention lower respiratory rates.

The heart rate in both study groups was relatively stable with a tendency to a moderate decrease. There were no significant differences between both groups. Our heart rate values were similar to those found by Ko et al. (1997). Heart rate values following the use of medetomidine, however, are lower when compared to other anaesthetics (Thurmon et al. 1994; Ko et al. 1994; Ko et al. 1996; Ko et al. 1997). Ko et al. (1997) described higher heart rates after the use of medetomidine and ketamine when compared to the use of medetomidine alone; the fact being caused by the effects of ketamine due to its direct stimulatory action on the central nervous system by increasing the concentration of circulating catecholamines influencing the central cardiovascular regulation mechanisms. The heart rate we found had a decreasing tendency similar to results by Ko et al. (1997). Values of heart rates following the use of the lower medetomidine and higher ketamine dose, however, were at lower levels at individual measurement times, which contradicts the common cardiovascular effects of medetomidine and ketamine and the age and body weight categories of our animals. Compared to the anaesthesia by xylazine and ketamine (Moreland and Glaser 1985), the heart rate values following the use of medetomidine and ketamine were at a lower level, which can be explained by marked cardiovascular effects of medetomidine.

In conclusion, the combination of medetomidine and ketamine for the anaesthesia of ferrets is very effective. It induces relatively long duration of anaesthesia, myorelaxation and analgesia, which can be prolonged by half ketamine doses. Comparing the previously used xylazine and medetomidine, it is possible to reduce ketamine doses and still maintain or even improve the anaesthetic parameters required.

\section{Použití kombinace medetomidin-ketamin ke krátkodobé anestezii fretek - klinická studie}

V klinické studii jsou u fretek srovnány anestezie kombinací medetomidinu s ketaminem ve dvou různých dávkách pro běžné chirurgické výkony (např. exstirpace paranálních žláz, kastrace nebo ovariohysterektomie. Fretkám byl intramuskulárně podán medetomidin $(60 \mu \mathrm{g} / \mathrm{kg})$ v kombinaci s ketaminem ve dvou různých dávkách $(5 \mathrm{mg} / \mathrm{kg}$ pro skupinu A a $8 \mathrm{mg} / \mathrm{kg}$ pro skupinu $\mathrm{B}$ ). Všechna zvířata během několika minut zaujímala laterální polohu a docházelo u nich ke ztrátě palpebrálního reflexu a hluboké citlivosti. Výjimkou byla 3 zvířata s nižší dávkou ketaminu, u nichž k vymizení hluboké citlivosti vůbec nedošlo. Nižší dávka ketaminu vyvolala pozdější vymizení všech námi sledovaných ukazatelů. Zkrátila dobu jejich znovuobnovení, zejména hluboké citlivosti. Její ztráta je u vyšší dávky ketaminu téměř dvojnásobně delší než u dávky nižší. Úroveň srdeční frekvence byla u obou skupin srovnatelná a měla klesající tendenci, dechová frekvence měla 
rovněž klesající tendenci, byla však počínaje 30 minutou u obou skupin zvířat odlišná. Kombinace medetomidinu s ketaminem je pro anestezii fretek velmi účinná z hlediska délky anestezie, myorelaxace a analgezie, které lze navíc časově prodloužit poloviční dávkou ketaminu.

\section{Acknowledgements}

This work was supported by the Ministry of Education, Youth and Sports of the Czech Republic (Research Project No. 161700002).

\section{References}

CREED, JE, KAINER, RA 1981: Surgical extirpation and related anatomy of sacs of the ferrets. J Amer Vet Med Assoc 179: 575-577

GREEN, CJ, HALSEY, MJ, PRECIOUS, S, WARDLEY-SMITH, B 1978: Alphaxolone-alphadolone anesthesia in laboratory animals. Lab Anim 12: 85-89

HAUPTMAN, K, TICHY, F, KNOTEK, Z 2001: Clinical diagnostics of hepatopathies in small mammals: evaluation of importance of individual methods. Acta Vet Brno 70: 297-311

KO, JC, BAILEY, JE, PABLO, LS, HEATON-JONES, TG 1996: Comparison of sedative and cardiorespiratory effects of medetomidine and medetomidine-butorphanol in dogs. Amer J Vet Res 57: 535-540

KO, JC, HEATON-JONES, TG, NICKLIN, CF 1997: Evaluation of the sedative and cardiorespiratory effects of medetomidine, medetomidine-butorphanol, medetomidine-ketamine, and medetomidine-butorphanolketamine in ferrets. J Amer Anim Hosp Assoc 33: 438-448

KO, JC, THURMON, JC, BENSON, GJ, TRANQUILLI, WJ, OLSON, SA, VAHA-VAHE, AT 1994: Hemodynamic and analgesic effects of etomidate infusion in medetomidine premedicated dogs. Amer J Vet Res 55: $842-846$

KO, JC, THURMON, JC, TRANQUILLI, WJ, BENSON, GJ, OLSON, WA 1992: A comparison of medetomidine-propofol and medetomidine.midazolam-propofol anesthesia in rabbits. Lab Anim Sci 42: 503507

MORELAND, AF, GLASER, C 1985: Evaluation of ketamine, ketamine-xylazine and ketamine-diazepam anaesthesia in the ferret. Lab Anim Sci 35: 287-290

PAYTON, AJ, PICK, JR 1989: Evaluation of combination of tiletamine and zolazepam as an anesthetic for ferrets. Lab Anim Sci 39: 243-246

SALONEN, JS 1989: Pharmacokinetics of medetomidine. Acta Vet Scand 85: 49-54

THURMON, JC, KO, JC, BENSON, GJ, TRANQUILLI, WJ, OLSON, SA. 1994: Hemodynamic and analgesic effects of propofol infusion in medetomidine premedicated dogs. Amer J Vet Res 55: 363-367

THURMON, JC, TRANQUILLI, WJ, BENSON, GJ 1996: Preanesthetics and anesthetic adjuncts. In: Lumb \& Jones Veterinary Anesthesia. (J. C. Thurmon, Ed.) 3 ${ }^{\text {ed }}$. Williams \& Wilkins, Baltimore, pp.183-209

VERSTEGEN, J, FARGETTON, X, DONNAY, I, ECTORS, F 1991: An evaluation of medetomidine/ketamine and other drug combinations for anaesthesia in cats. Vet Rec 128: $32-35$ 